\title{
Silviculture Agroforestry Regime: Compatible Management in Southern Gunung Merapi National Park, Java, Indonesia
}

\author{
Priyono Suryanto (Corresponding author) \\ Faculty of Forestry, Gadjah Mada University, Yogyakarta, Indonesia \\ Telephone: +62 274 550542, E-mail: psuryanto@ugm.ac.id \\ Mohd.Zaki Hamzah \\ Faculty of Forestry, Universiti Putra Malaysia, Selangor, Malaysia \\ E-mail: zakihamzah@ymail.com \\ Azmy Mohamed \\ Faculty of Forestry, Universiti Putra Malaysia, Selangor, Malaysia \\ E-mail: Azmy5868@putra.upm.edu.my \\ Moh.Azani Alias \\ Faculty of Forestry, Universiti Putra Malaysia, Selangor, Malaysia \\ E-mail: azani@putra.upm.edu.my
}

Received: October 09, 2010 Accepted: October 22, 2010 doi:10.5539/ijb.v3n2p115

\begin{abstract}
Silviculture agroforestry regime (SAR), which is a compatible management with forest rehabilitation and also renewal zoning system of the national park, was started to increase the agroforestry productivity surrounding Gunung Merapi National Park (GMNP). In addition, SAR also supported the basic information succession of Mount Merapi eruption in 2006 to strengthen Merapi lava tour. This is an innovative step in developing GMNP, in which its pro-poor conservation is not only based on land productivity, but also based tourism. This study was begun with the development of a permanent plot to study succession (May 2008-Novemper 2009), and the impact of community intervention on grass stock at GMNP, as well as to assess agroforestry typology and its implication on the areas surrounding GMNP. SAR was developed using landuse model based on limiting the factor of each agroforestry cluster. Choosing the treatment in SAR refers to the actual condition and opportunity every agroforestry cluster and sensitivity analysed until the intervention on the GMNP was minimal. The implementation of SAR was done with a software known as Stella 9.0. There are five SAR models which are appropriate for agroforestry cluster (AF); these are labelled as AF1-SAR1, AF2-SAR2, AF3-SAR3, AF4-SAR4 and AF5-SAR5. SAR is based on resources sharing whereby space is arranged through crown pruning and also rationalization number of dairy cows. In addition, SAR has a packet management for synergizing function of private lands (homegarden, dry field and land village as a unit management) and intensification by land tillage, renewal of grass and fertilization. In particular, SAR1-5 has the ability to balance agroforestry management with decreasing local community intervention and increasing biodiversity level on GMNP. The ratio for grass productivity outside GMNP with grass necessity and implementation of SAR was close to an optimum point (1). Meanwhile, the ratio values of SAR1-5 were $0.982,1.010,1.44,1.047$ and 1.253 , respectively. Nonetheless, the implementation of SAR needs more technology of silviculture agroforestry and a full support from stakeholders.
\end{abstract}

Keywords: Silviculture, Agroforestry, Compatible management, National park

\section{Introduction}

Forest resources degradation throughout the world have various consequences, including shifting paradigm in management. The shifting is based on different terms, which refer to the effort to 'sustain' the flows of different 
sets of forest goods and services beginning from sustainable yield forestry, sustainable forestry and sustainable forest management (Sayer and Maginnis, 2005). It can also be used for more protected areas as supported conservation. Currently, there are around 100,000 protected areas in the world, covering over $12 \%$ of the Earth's land surface (Chape et al., 2005). Unfortunately, many protected areas are only 'paper parks' which not only face serious degradation, but they are also the targets of continuous exploitation (Curran et al., 2004).

In Indonesia, one of the models for protected area which is gaining rapid popularity is national park. At present, there are more than 50 new national parks, which were established since 2004 (Ministry of Forestry, 2006). Nevertheless, the unique characteristics of these protected areas in Indonesia, especially national park, have potential conflicts with the local community. The challenge in developing countries is a daunting task and is largely unmet to reconcile conservation and improvement of forest livelihoods (Sunderlin et al., 2005). In many cases, biodiversity conservation may conflict with the efforts to reduce poverty (Adams et al., 2004). The existing relationship between national park and local community as a negation, in legal formal national park management damages local community (win-loss) because of the prohibition to harvest (i.e. grass and wood) on the national park zone. In real, the local community has intervened on the national park areas (loss-win) through harvesting of grass on all kinds of the zone of national park.

Breaking the cycle between poverty and land intervention in GMNP can be done by employing strategies that empower farmers economically and promote sustainable agroforestry intensification using efficient, effective and affordable silviculture agroforestry technologies. Based on this, a schema compatible management between national park and local community surrounding southern GMNP through silviculture agroforestry regime is fundamental innovation. One way of identifying the compatibility is when managing forests simultaneously produces wood and other resources without contributing to the reduction of other resources (Hayness et al., 2003).

However, the development of national parks in Indonesia, many of the buffer zones of national parks have not intensively managed. SAR can be used as an early step in designing agroforestry systems. Strengthening is needed in order to maintain the conservation values of potential buffer zones for the future (Thorell and Gotmark, 2005). This approach can be effective as there is a possible need to adapt the design and management of agroforestry systems to better reflect the objectives, resources, attitudes and opportunities facing each particularly landholder (Nuberg et al., 2009).

Besides that, SAR also prepares strategic steps based on tourism. The eruption of Mount Merapi in 2006 gives unique information about lava which disturbed Kaliadem recreation park, which has recently become an alternative promising location for tourism. Thus, succession information can be used to support and strengthen Merapi lava tour. In short, SAR has designed win-win conservation in management of GMNP that is pro-poor conservation. The goal of conservation is redefined based on the pro-poor conservation approach; from the "conservation through poverty reduction", i.e. poverty reduction as a means for conservation towards "poverty reduction through conservation", and conservation as a means to reduce poverty (Barber, 2004). This study was aimed at arranging silviculture agroforestry regime model based on the synergized intensive agroforestry outside the national park that is compatible with the forest rehabilitation and renewal zoning system in GMNP.

\section{Methods}

\subsection{Study site}

The study area was in the district of Sleman, which include Kaliadem and Jambu Villages, and Cangkringan regency to asses the typology of agroforestry and its implication on surrounding GMNP (Suryanto et al., 2010a). A survey study was carried out on local community which practice agroforestry in Kaliadem and Jambu Villages. The sampling technique for this study was the purposive sampling, in which the respondents were randomly chosen based on the data on their social status retrieved from the local authorities. Stand structure measurement was done by the census technique to all land types by the selected respondents. Meanwhile, the respondents were also interviewed to gather information on their social economic aspect. In this study, the total number of the respondents at Kaliadem was 35 and 16 for Jambu (Figure 1).

The study also assessed the impact of community intervention on grass stock at GMNP (Suryanto et al., 2010b). A line plot sampling methods applied in this study was based on the distance between the villages (Kaliadem and Jambu) and the national park. The study area was divided into five zones, which Zones I, II, III, and IV, with the transect size of $300 \mathrm{~m}$ crosswise and following the direction of slope. For Zone V, the transect size of $1200 \mathrm{~m}$ following the direction of slope (Figure 1).

An early information of succession that caused Merapi eruption in 2006 is also supported in SAR. The 
information regarding species diversity at the early stage of succession (Suryanto et al., 2010c), dynamics species (Suryanto et al., 2010d) and also prospective pioneer species (A. decurrens) as standing stocks for wood fuel by the local community (Suryanto et al., 2010e) can be used as a basic patterning silviculture after the eruption, especially to accelerate rehabilitation and maintain the pioneer potential. This information contributes to be additional of references on the succession for restoration, and vice versa (Walker and del Moral, 2003).

\subsection{Data analysis}

The analysis was started with multidimensional scaling (Borg and Groenen, 2005) and cluster analysis (MacKay, 2003) for every land type surrounding the southern of GMNP. The parameters of the multidimensional scaling and the cluster analysis included tree regeneration (namely, percentage of seedlings, sapling, poles and trees). The second parameter used is the status of the trees, i.e. the stand monoculture characteristic, the percentage of fast growing species, commercial trees and multipurpose tree species, tree volume and diversity index. Meanwhile, the agricultural aspect includes grass, crop and horticultural coverage.

The final parameter is the social economic aspect such as the farmers' age, level of education, number of family members, number of family members who are productive, the number of dairy cows, the size of homegarden, dry field, village land and lahan andil (i.e. a piece of state land forest that is temporarily cultivated by forest farmers for agricultural crops). In this study, the tree volume, grass percentage, grass productivity, grass necessity and the ratio for the land productivity-grass necessity were counted using the following equations:

Trees volume (West, 2009):

$$
\begin{aligned}
& \mathrm{V}_{\mathrm{i}}=\frac{1}{4} \mathrm{dbh}_{\mathrm{i}}{ }^{2} \mathrm{xhfb}_{\mathrm{i}} \times 0.7 \\
& \mathrm{~V} / \mathrm{ha}=\frac{\sum_{i=1}^{n} V_{i}}{A}
\end{aligned}
$$

Where $\mathrm{V}_{\mathrm{i}}=$ trees volume to $\mathrm{i}, \mathrm{dbh}_{\mathrm{i}}=$ diameter at breast height trees to $\mathrm{i}, \mathrm{hfb}=$ height free branch trees to $\mathrm{i}, \mathrm{V} / \mathrm{ha}=$ volume per ha $\left(\mathrm{m}^{3} / \mathrm{ha}\right)$ and $\mathrm{A}=$ land size (ha).

Grass percentage: $\mathrm{G}_{\mathrm{j}}=\frac{A G_{j}}{A T_{j}} \times 100$

Where $G_{j}=$ grass coverage percentage (\%) of private land to $j, A_{j}=$ grass coverage (ha) of private land to $j$, and $\mathrm{AT}_{\mathrm{j}}=$ total land size (ha) of private land to $\mathrm{j}$.

Grass productivity: $G P_{j}=\frac{G_{j} \times A_{j} \times W G}{A G \times R \times 30}$

Where $\mathrm{GP}=$ grass productivity at private land to $\mathrm{j}(\mathrm{kg} / \mathrm{day}), \mathrm{G}=$ grass percentage at private land to $\mathrm{j}, \mathrm{A}=$ total size of the private land to $\mathrm{j}, \mathrm{AG}=$ average size for get 1 bunch grass $\left(25 \mathrm{~m}^{2}=0.00025 \mathrm{ha}\right.$, from the study $), \mathrm{WG}=$ heavy average 1 bunch grass $(60 \mathrm{~kg}$, from the study) and $\mathrm{R}=$ rotation average of grass harvesting 3.8 month based on the average grass harvesting on dry season (5.5 month) and raining season ( 2.1 month) during the study period.

Grass necessity: $C_{j}=N C_{j} * G C_{j}$

Where $\mathrm{C}_{\mathrm{j}}=$ the number of grass necessity ( $\mathrm{kg} /$ day) farmer to $\mathrm{j}, \mathrm{NC}=$ number dairy cow farmer to $\mathrm{j}$, and $\mathrm{GC}_{\mathrm{j}}=$ grass necessity by 1 dairy cow per day $(30 \mathrm{~kg} /$ day, from the study).

Ratio land productivity-grass necessity: $R G P_{i}=\frac{G P_{j}}{C_{j}}$

Where $\mathrm{RGP}_{\mathrm{j}}=$ ratio grass productivity at private land with grass necessity, $\mathrm{GP}_{\mathrm{j}}=$ grass productivity at private land to $\mathrm{j}\left(\mathrm{kg} /\right.$ day) and $\mathrm{C}_{\mathrm{j}}=$ number of grass necessitated $(\mathrm{kg} /$ day) by farmer to $\mathrm{j}$.

The next step is the discriminant analysis (Zuur et al., 2007) to identify the variables that determine clustering, and this is followed by calculating the amount of interaction for each agroforestry cluster towards GMNP which is representative amount of land private, lahan andil and intervention index every agroforestry cluster. 
Finally, this study was done using the landuse model based on the limiting factor of each agroforestry cluster. The regression analysis was conducted to determine the relationship between the variables through a mathematic model. SAR was implemented using a software known as Stella 9.0. Based on the model formed at every agroforestry cluster, the SAR would define the type for decreasing intervention on GMNP. Choosing the treatment in SAR refers to the actual condition and the opportunity for every agroforestry cluster. The sensitivity was analysed until the intervention on GMNP reached a minimum value.

\section{Results}

\subsection{The characteristic agroforestry surrounding GMNP}

It is important to note that the land use based on agroforestry surrounding GMNP consists of homegarden, dry field and land village. Agroforestry classifies five clusters, namely AF1, AF2, AF3, AF4 and AF5. Based on the grass productivity, AF3 is the cluster with a surplus stock of grass. Meanwhile, there is a deficit status of grass productivity at AF1, AF4, AF5 and AF2 (Table 1).

Generally, the type of grass productivity crisis showed that AF1 has a typology with a big number of dairy cow (7), small private land, landuse management intensively (crown coverage $<30 \%$ ) and high of grass productivity $(>120 \mathrm{~kg} / \mathrm{ha} /$ day). AF2 with typology medium number of dairy cow (4.17), small private land, have an opportunity to prune of the crown because the coverage still above $52 \%$ and high of grass productivity ( $>120$ $\mathrm{kg} / \mathrm{ha} /$ day).

AF4 with typology medium number of dairy cow (3.93), relatively big private land, have an opportunity to prune of the crown because the coverage still above $70 \%$ and the grass productivity has an opportunity to increase $(<120 \mathrm{~kg} / \mathrm{ha} /$ day). The typology of AF5 is a high number of dairy cow (8), relatively big private land, intensive landuse with crown coverage $<30 \%$ and high of grass productivity ( $>120 \mathrm{~kg} / \mathrm{ha} /$ day).

The homegarden system has a similarity trend in terms of crown coverage, i.e. with more than $80 \%$ crown coverage (number of trees 200-486 per ha) and grass productivity (about 7.895-41.105 kg/day/ha). AF5 has the highest grass productivity in the homegarden system $(41.105 \mathrm{~kg} /$ day/ha), while the lowest is at AF1 (7.895 $\mathrm{kg} / \mathrm{day} / \mathrm{ha})$. The highest grass productivity of village land is at AF1 (153.947 $\mathrm{kg} / \mathrm{day} / \mathrm{ha})$ with a crown coverage $<30 \%$. Generally, the village land has similarity with low crown coverage and a big space for grass area. As for $\mathrm{AF} 3$, it has a lot of trees (830.268 trees/ha) and also a high grass productivity $(153.158 \mathrm{~kg} / \mathrm{day} / \mathrm{ha})$ as shown in Table 1.

Generally, the trend relation between crown and grass coverage for all the agroforestry clusters is shown in the cubic model. When the number of trees is from 0-600/ha, the grass coverage decreases but when the number of trees is more than 600/ha, the grass coverage increases. This is on the contrary to the crown coverage and the number of trees, whereby the coverage increases when the number of trees is from $0-600 /$ ha but it decreases when the number of trees exceeds 600/ha (Figure 2).

The relationship between crown and grass productivity is according to the quadratic trend. This means that the grass productivity at a crown coverage of $0-40 \%$ increases, but the productivity decreases if the crown coverage $>$ $40 \%$, as shown in Figure 3.

\subsection{Schematic model of SAR}

Silviculture Agroforestry Regime (SAR) was designed to increase the productivity of agroforestry to be compatible with forest rehabilitation and renewal of zoning system at GMNP. This design is simultaneously done between intensive agroforestry and management of GMNP. In addition, SAR also gives the opportunity for GMNP to community empowerment through buffer zone intensification based on agroforestry. Meanwhile, the forest rehabilitation regime and renewed zoning system of GMNP give the opportunities to the local community to encourage sustainable and prospective GMNP.

SAR model is connected with the situational formulation in GMNP such as conservation scheme, intervention index and grass harvesting (Suryanto et al., 2010b). The model of the conservation scheme has the formula of $\mathrm{H}=0.709-0.629 \mathrm{I}(\mathrm{H}=$ diversity index and $\mathrm{I}=$ intervention index $)$ and $\mathrm{r}^{2}=0.657$, $\mathrm{p}$-value $=0.027$. The estimation of grass harvesting for every scheme was done based on the allometric model between the variables for intervention and grass harvesting, using the formula, $\mathrm{GH}=176.820 \mathrm{I}^{0.482}$ ( $\mathrm{GH}=$ grass harvesting $(\mathrm{kg} / \mathrm{day})$ and $\mathrm{I}=$ intervention index) with $\mathrm{r}^{2}=0.949 \mathrm{p}$-value $=0.005$. The relationship intervention index with ratio grass productivity at private land with grass necessity, using the formula, $\mathrm{I}=0.970-0.141 \mathrm{RGP}-1.31 \mathrm{RGP}^{2}+0.678 \mathrm{RGP}^{3}$ with $\mathrm{r}^{2}=0.979$ and $\mathrm{p}$-value $=0.000(\mathrm{RGP}=$ ratio grass productivity at private land with grass necessity, $\mathrm{I}=$ intervention index $)$. Based on this formulation, the model is composed as shown in Figure 4. 
There are five SAR models with appropriate agroforestry cluster (AF); these are AF1-SAR1, AF2-SAR2, AF3-SAR3, AF4-SAR4 and AF5-SAR4. SAR is based on resource sharing, with space arrangement done through crown pruning and rationalization of the number of dairy cows. In addition, SAR has packet management for synergizing function land private (homegarden, dry field and village lands as a unit management) and intensification by land tillage, renewal of grass and fertilization. Based on the simulation, SAR 1 to SAR 5 has the ability to balance agroforestry management and decrease the local community's intervention, but increase the level of biodiversity at GMNP (Table 2).

Based on resource sharing in the agroforestry system, all SAR models (SAR 1 to SAR 5) has space allocation for trees and grass. Besides that, rationalization in the number of dairy cows is important to ensure balance in the capacity for grass stocking and the number of dairy cows. SAR3 can be used a reference for intensive agroforestry, particularly for the grass productivity over stock. In SAR3, scheme rationalization and the increasing number dairy cows is from 2.75 to 7 . Nonetheless, this is different for SAR1 and SAR4, with the rationalization and decreasing number of cows from 7 to 5 and 8 to 6 , respectively. Thus, transformation effort from rationalization through intensification of trees in agroforestry system is important, and this can be done by enrichment planting with fast growing species.

The ratio for grass productivity outside GMNP with grass necessity after the implementation of SAR is close to the optimum point (1). Meanwhile, the ratio values for SAR 1 to SAR 5 are 0.982, 1.010, 1.44, 1.047 and 1.253, respectively (Figure 5).

The implementation of SAR at the early stage was still based on the management buffer zone through intensive agroforestry which is compatible with the forest rehabilitation and renewal zoning system at GMNP. Another potential of the southern GMNP is the unique characteristic of the area disturbed following the 2006 Merapi eruption. Recently, the new location has become popular with the Merapi lava tour. The succession of Merapi can be used as an important information to attract tourists. This includes succession information such as species diversity during the early succession, dynamic species and also potential pioneer species (Acacia decurrens) as an energy stock (woodfuel) by local community surrounding GMNP. Based on this information, the SAR scheme uses succession information as crucial information outside the optimalization buffer zone. This is as an innovative step to support GMNP prospective through pro-poor conservation based on tourism.

\section{Discussion}

\subsection{GMNP and agroforestry management regime}

Indonesia national park development refers to ministerial decree about collaboration management (Ministry of Forestry-Indonesia, 2004). Based on this, the zoning reform synergy was prepared to outline the rules for the park and the aspiration of the local community that combine the principles of silviculture forest rehabilitation and intensive reform traditional zone, which is a fundamental strategy for the new management of Merapi area through GMNP (Suryanto et al., 2010c).

In this scheme, silviculture rehabilitation on GMNP develops blocks of seed sources into force self-regeneration, both of endemic species, in situ and ex situ conservation, species commercial that supports non-wood forest products and herbal potentials. Moreover, the space of GMNP forest stand is maximized with efipit potential (Vanda tricolour) and ornamental plants (Medinella speciosa and Nepenthes alata) and plants/herbs with medicinal properties (such as Cinchona ledgeriana, Andrographis paniculata and Java Chili for diversification).

Non-wood forest products and innovation objects of recreation, as well as healthcare through medical plant conservation, wild species as food, wild species as food stores, sacred groves, and pro-poor nature tourism (Roe and Elliott, 2003). Maintaining forest biodiversity can be achieved by implementing large-scale naturalistic silvicultural management and adequate network of protected areas, which synergize conservation of product and non-product functions (Parviainen and Frank, 2003). Reconciling the production of wood with the recreational and ecological functions of the forest ecosystems is a main challenge for modern silviculture. Most of this challenge regards the development of close-to-nature silvicultural systems, based on the natural "self-regeneration" (Bergeron and Harley, 1997; Huttl et al., 2000; Schutz, 2001).

Agroforestry practice in the areas surrounding southern GMNP is based on grass productivity (Suryanto et al., 2010b) which is largely dominated by deficit grass stock. This condition gives an implication on the local community's intervention of the GMNP area to support grass stock. AF1 is the cluster with the highest intervention level on GMNP, followed by AF2 and AF4. Meanwhile, AF3 and AF5 had relatively low interventions. It is important to note that the high intervention from the local community evokes disturbing biodiversity on GMNP. Pasture practices resulting from land abandonment significantly influences the structure 
and function of the ecosystem (Farris et al., 2010).

\subsection{Silviculture agroforestry regime compatible with GMNP management}

Based on the simulation, every SAR has the ability to balance agroforestry management with the decreasing local community intervention close to zero and increasing biodiversity level on GMNP more than 0.7. In particular, cluster AF1-5 showed that grass productivity increased with the crown coverage below $40 \%$, and vice versa. SAR is based on pruning technology because there is a significant viable space for optimal grass growth. In an agroforestry system, short wave radiation allocation below the covering of the trees is significant to the annual crops growing beneath them (Zhao et al., 2003). The pruning technique in the SAR model is a variable lift pruning, although it is more complex than the fixed-lift pruning (Montagu et al., 2003). Thus, agroforestry is considered to have a high level of diversity with many species and different ages with the effort to increase productivity by not decreasing the level of biodiversity. This particular strategy was also developed in the sustainable management of Swedish semi-natural pastures with high species diversity (Kumm, 2003).

Lands carrying the capacity for grass productivity and the number of dairy cows are very significant for the intervention level at GMNP. SAR2 and SAR5 have a balanced ratio between the number of dairy cows and grass productivity; therefore, productivity can be increased based on the pruning regime for about $10 \%$ and $30 \%$ of the crown coverage, respectively. A pruning intensity below $50 \%$ of the total height is therefore, recommended (Perez and Kanninen, 2003). For SAR1 and SAR4, however, rationalisation with decreasing number of dairy cows is needed to balance productivity in the agroforestry system and maintain biodiversity in GMNP. SAR has a packet management for private land synergizing function (homegarden, dry field and village lands as a management unit) and intensification by land tillage, renewal of grass and fertilization.

Configuration agroforestry in the areas surrounding the southern part of GMNP with the SAR scheme is not only an asset for a compatible management between the local community and national park management, but it also an important source for intensive management of the buffer zone systems. In fact, the local communities can participate in decision making, particularly in the conservation and resource management of the surrounding lands or buffer zones to encourage the protected areas to become more effective (Hansen and DeFries, 2007; DeFries et al., 2007). Besides that, community forest management also plays an effective role in forest conservation (Ellis and Bolland, 2008). Moreover, the potential to contribute to the conservation of biodiversity through traditional and local ecological knowledge has widely been recognized (Charnley et al., 2007).

Merapi lava tour, which is a promising strategy in the development of GMNP, is not only based on land productivity, but it also serves as a recreation basis. In fact, the GMNP management with a unique value through recreation has become a new prospect for pro-poor conservation. In order to achieve this, the government of Indonesia established Gunung Merapi museum in 2009 in Hargobinangun village, Pakem regency and Sleman district (Ministry of Energy and Mineral Resources, 2009). The Merapi's succession post eruption 2006 will provide information to synergize tourist attraction. The demand for ecotourism and outdoor recreation in developed and developing countries is increasing. In modern forestry, especially in the developed countries with high land purchasing costs, timber generates very low returns (Font and Tribe, 2000); therefore, bringing tourism and forestry together has been recognized as important in the forest management (JongHo et al., 1997). In short, preparing SAR which supports tourism is promising in the future.

\subsection{Implications for management}

SAR which is compatible with the management of GMNP constitutes synergized goal, i.e. to increase conservation function and production. The natural enemies of biodiversity conservation and biological control are compatible and in many cases, they may also be complementary goals (Straub et al., 2008). The implementation of SAR needs more technology for silviculture agroforestry. The concepts of 'from homogeneity to heterogeneity', 'from simplicity to complexity' and 'from an agricultural system to a natural disturbance-based system' have widely been recognized in alternative silviculture (Mizunaga et al., 2010). In addition, conservation policy should be engaged through technical assistance, environmental education and incentive schemes (Plieninger, 2007).

\section{Conclusion}

In short, the implementation of SAR requires a full support from stakeholders. Technology- and policy-based are two examples represent the extremes in the delivery of agroforestry research (Sanchez, 1999). Without a sound technical documentation, the GMNP management as a SAR would not be as receptive to the suggested policy options. Similarly, without enabling policies, the breakthroughs in compatible management replenishment would not go far. Stakeholders, particularly local citizenry-must are motivated to assume responsibility in a partnership 
(Aronson et al., 2006). SAR also needs to promote conservation policy maker, advancement in the incorporation of state-and-transition models into the structure-function conceptual framework, and implementation of this approach by land managers and restoration practitioners (Cortina et al., 2006). Through SAR scheme, GMNP will have a new management approach and may be promising to the national park reference in Indonesia, particularly for the pro-poor conservation programme which is compatible with the intensive management buffer zone.

\section{References}

Adams, W.M., Aveling, R., \& Brockington, D. (2004). Biodiversity conservation and the eradication of poverty. Science, 306, 1146-1149.

Aronson, J., Clewell, A.F., Blignaut, J.N., \& Milton. S.J. (2006). Ecological restoration: A new frontier for nature conservation and economics. Journal for Nature Conservation, 14, 135-139.

Barber, C.V. (2004). Parks and people in a world of changes: Governance, participation and equity. In: C.V. Barber, K.R. Miller \& M. Boness (Eds.), Securing Protected Areas in the Face of Global Change: Issues and Strategies, pp. 97-134. IUCN, Gland, Switzerland and Cambridge, UK.

Bergeron, Y., \& Harley, B. (1997). Basing silviculture on natural ecosystem dynamics: an approach applied to the southern boreal mixed wood forest of Quebec. Forest Ecology Management, 92, 235-242.

Borg, I., \& Groenen, P. (2005). Modern multidimensional scaling: theory and applications (2nd ed.), Springer-Verlag New York.

Chape, S., Harrison, J., Spalding, M., \& Lysenko, I. (2005). Measuring the extent and effectiveness of protected areas as an indicator for meeting global biodiversity targets. Philosophical Transactions of the Royal Society of London Biological Sciences, 360, 443-455.

Charnley, S., Fischer, A. P., \& Jones. E. T. (2007). Integrating traditional and local ecological knowledge into forest biodiversity conservation in the Pacific Northwest. Forest Ecology and Management, 246, 14-28.

Cortina, J., Maestre, F.T., Vallejo, R., Baeza, M.J., Valdecantos, A., \& Pe'rez-Devesa, M. (2006). Ecosystem structure, function, and restoration success: Are they related? Journal for Nature Conservation, 14, 152-160.

Curran, L.M., Trigg, S.N., \& McDonald, A.K. (2004). Lowland forest loss in protected areas of Indonesian Borneo. Science, 303, 1000-1003.

DeFries, R., Hansen, A., Turner, B.L., Reid, R., \& Liu, J., (2007). Land use change around protected areas: management to balance human needs and ecological function. Ecological Applications, 17 (4), 1031-1038.

Ellis, E.A., \& Bolland, L.P. (2008). Is community-based forest management more effective than protected areas? A comparison of land use/land cover change in two neighboring study areas of the Central Yucatan Peninsula, Mexico. Forest Ecology and Management, 256, 1971-1983.

Farris, E., Filigheddu, R., Deiana, P., Farris, G.A., \& Garau, G. (2010). Short term effect son sheep pasture land due to grazing abandonment in a Western Mediterranean is land ecosystem. A multidisciplinary approach. Journal for Nature Conservation, doi:10.1016/j.jnc.2009.11.00.

Font, X,. \& Tribe, J. (2000). Recreation, conservation and timber production: a sustainable relationship? In: X, Font \& J. Tribe (Eds.), Forest tourism and recreation: case studies in environmental management, pp. 1-22. CABI Publishing.

Hansen, A.J., \& DeFries, R. (2007). Ecological mechanisms linking protected areas to surrounding lands. Ecological Applications .27 (4), 974-988.

Hayness, R.W., Monserud, R.A., \& Johnson, A.C. (2003). Compatible forest management: Background and context. In: R.W. Hayness, R.A. Monserud, A.C. Johnson (Eds.), Compatible Forest Management pp. 3-34. Kluwer Academic Publisher.

Huttl, R.F., Schneider, B.U., \& Farrell, E.P. (2000). Forest of the temperate region: gaps in knowledge and research needs. Forest Ecology and Management, 132, 83-96.

JongHo, K., KyuHun, K., \& ChinKyu, L. (1997). A study on the establishment of classification index for choosing the objective areas of mountain village region development project. Journal of Forest Science, 55, 105-124.

Kumm, K.I. (2003). Sustainable management of Swedish seminatural pastures with high species diversity. Journal for Nature Conservation, 11, 117-125. 
MacKay, D. (2003). An example inference task clustering: Information theory, inference and learning Algorithms. Cambridge University Press.

Ministry of Energy and Mineral Resources. (2009). Press release, Establishing Gunung Merapi Museum. Directorate Geology, Ministry of Energy and Mineral Resources, Indonesia. http://www.esdm.go.id/

Ministry of Forestry. (2004). Ministerial decree on collaboration for the management of protected areas (No.19/Menhut-II/2004). Ministry of Forestry, Jakarta. www.dephut.go.id/informasi/skep/2004/p19_04., htm.

Ministry of Forestry. (2006). Recognizing 21 national park in Indonesia. General directorate of forestry protection and nature conservation, Jakarta, Indonesia. [online] Available :http://www.dephut.go.id (February 3, 2010).

Mizunaga, H., Nagaike, T., Yoshida, T., \& Valkonen, S. (2010). Feasibility of silviculture for complex stand structures: designing stand structures for sustainability and multiple objectives. Journal of Forest Research, 5:1-2.

Montagu, K.D., Kearney, D.E., \& Smith, R.G.B. (2003). The biology and silviculture of pruning planted eucalypts for clear wood production-a review. Forest Ecology and Management, 179, 1-13.

Nuberg, I., Reid, R., \& George, B. (2009). Agroforestry as integrated natural resource management. In: I. Nuberg, B. George \& R. Reid (Eds.), Agroforestry for natural resource management. CSIRO Publishing.

Parviainen, J., \& Frank. G. (2003). Protected forests in Europe approaches-harmonising the definitions for international comparison and forest policy making. Journal of Environmental Management, 67, 27-36.

Perez, D., \& Kanninen, M. (2003). Provisional equations for estimating total and merchantable volume of Tectona grandis trees in Costa Rica. Forests, Trees \& Livelihoods, 13, 345-359.

Plieninger, T. (2007). Compatibility of livestock grazing with stand regeneration in Mediterranean holm oak parklands. Journal for Nature Conservation, 15, 1-9.

Roe, D., \& Elliott, J. (2003). Pro-poor conservation: the elusive win-win for conservation and poverty reduction? Paper presented at the Vth IUCN World Parks Congress, Durban, South Africa. September 8-17.

Sanchez, P.A. (1999). Delivering on the promise of agroforestry. Environment, Development and Sustainability, $1,275-284$.

Sayer, J.A., \& Maginnis, S. (2005). New challenges for forest management. In: J.A. Sayer, \& S. Maginnis (EDS.), Forest in Lanscapes: Ecosystem approaches to sustainability. Earthscan.

Schutz, J.P. (2001). Opportunities and strategies of transforming regular forests to irregular forests. Forest Ecology and Management, 151, 87-94.

Straub, C.S., Finke, D.L., \& Snyder, W.E. (2008). Are the conservation of natural enemy biodiversity and biological control compatible goals? Biological Control, 45, 225-237.

Sunderlin, W. D., Angelsen, A., Belcher, B., Burgers, P., Nasi, R., Santoso, L., \& Wunder. S. (2005). Livelihoods, forests, and conservation in developing countries: an overview. World Development, 33 (9), 1383-1402.

Suryanto, P., Zaki, M.H., Azani,M.A., \& Azmy,M. (2010c). Species diversity of Gunung Merapi National Park, Java, Indonesia following 2006 eruption. Res.Environ.Life Sci. Research in Environmental and Life Science, 3 (1), 1-6.

Suryanto, P., Zaki, M.H., Azani,M.A., \& Azmy,M. (2010d). Post-eruption species dynamic of Gunung Merapi National Park, Java, Indonesia. Journal of Tropical Biology \& Conservation, 7:49-57.

Suryanto, P., Zaki, M.H., Azmy,M., \& Azani,M.A. (2010a). Agroforestry typology and its implications on surrounding South Region of Gunung Merapi National Park, Java, Indonesia. The Malaysian Forester, 73 (2), 229-238.

Suryanto, P., Zaki, M.H., Azmy, M., \& Azani, M.A. (2010b). Impact of community intervention on grass stock at Gunung Merapi National Park (Southern), Java, Indonesia. Research in Environmental and Life Science, (in press).

Suryanto, P., Zaki, M.H., Azmy, M., \& Azani, M.A. (2010e). The dynamic growth and standing stock of Acacia decurrens following the 2006 eruption in Gunung Merapi National Park, Java, Indonesia. International Journal of Biology, 2 (2), 165-170. 
Thorell, M., \& Gotmark, F. (2005). Reinforcement capacity of potential buffer zones: Forest structure and conservation values around forest reserves in southern Sweden. Forest Ecology and Management, 212, 333-345.

Walker, L.R. \& del Moral R. (2003). Primary succession and ecosystem rehabilitation. Cambridge: Cambridge University Press.

West, P.W. (2009). Tree and Forest Measurement. Second Edition. Springer.

Zhao, W., Qualls, R.J., \& Berliner, P.R. (2003). Modeling of the short wave radiation distribution in an agroforestry system. Agricultural and Forest Meteorology, 118, 185-206.

Zuur, AK., Ieno, E.N., \& Smith, G.M. (2007). Analyzing ecological data. Springer.

Table 1. Characteristic agroforestry surrounding Southern GMNP

\begin{tabular}{|c|c|c|c|c|c|c|c|c|c|}
\hline \multirow{2}{*}{\multicolumn{2}{|c|}{ landuse }} & \multirow{2}{*}{$\begin{array}{l}\text { land } \\
\text { size } \\
\text { (ha) }\end{array}$} & \multirow{2}{*}{$\begin{array}{c}\sum \text { trees } \\
\text { and poles } \\
\text { ha }^{-1}\end{array}$} & \multirow{2}{*}{$\begin{array}{c}\text { crown } \\
\text { coverag } \\
\mathrm{e}\end{array}$} & \multirow{2}{*}{$\begin{array}{c}\text { grass } \\
\text { productivity } \\
(\mathrm{kg} / \text { day } / \mathrm{ha})\end{array}$} & \multirow{2}{*}{$\begin{array}{c} \\
\text { dairy } \\
\text { cow }\end{array}$} & \multirow{2}{*}{$\begin{array}{c}\text { lahan } \\
\text { andil } \\
\text { (ha) }\end{array}$} & \multicolumn{2}{|c|}{ grass $\quad(\mathrm{kg} /$ day $)$} \\
\hline & & & & & & & & $\begin{array}{c}\text { grass } \\
\text { necessity }\end{array}$ & $\begin{array}{l}\text { deficit (-)/ } \\
\text { surplus (+) }\end{array}$ \\
\hline $\mathrm{AF}$ & homegarden & 0.039 & 200.000 & 0.820 & 7.895 & & & & \\
\hline 1 & dry field & 0.500 & 51.282 & 0.157 & 150.001 & 7 & 0.871 & 210 & -62.645 \\
\hline & land village & 0.468 & 315.392 & 0.200 & 153.947 & & & & \\
\hline $\mathrm{AF}$ & homegarden & 0.095 & 545.946 & 0.781 & 10.276 & & & & \\
\hline 2 & dry field & 0.509 & 198.766 & 0.520 & 89.886 & 4.17 & 0.333 & 125 & -16.053 \\
\hline & land village & 0.406 & 334.016 & 0.203 & 153.158 & & & & \\
\hline $\mathrm{AF}$ & homegarden & 0.075 & 386.824 & 0.773 & 20.570 & & & & \\
\hline 3 & dry field & 1.614 & 321.580 & 0.704 & 112.782 & 2.75 & 0.063 & 82.500 & 133.779 \\
\hline & land village & 0.213 & 830.268 & 0.250 & 153.158 & & & & \\
\hline $\mathrm{AF}$ & homegarden & 0.042 & 444.237 & 0.756 & 17.479 & & & & \\
\hline 4 & dry field & 1.182 & 220.257 & 0.194 & 131.707 & 8 & 0.217 & 240 & -51.402 \\
\hline & land village & 0.210 & 294.026 & 0.186 & 153.383 & & & & \\
\hline $\mathrm{AF}$ & homegarden & 0.075 & 486.391 & 0.702 & 41.105 & & & & \\
\hline 5 & dry field & 0.926 & 288.367 & 0.709 & 101.889 & 3.93 & 0.083 & 118 & -20.511 \\
\hline & land village & 0.000 & 0.000 & 0.000 & 0.000 & & & & \\
\hline
\end{tabular}


Table 2. SAR schemes based on simulation and sensitivity analysis

\begin{tabular}{|c|c|c|c|}
\hline $\begin{array}{l}\text { Agroforestry } \\
\text { cluster }\end{array}$ & $\begin{array}{c}\text { SAR } \\
\text { Model }\end{array}$ & Description simulation & Package Management \\
\hline AF1 & SAR1 & $\begin{array}{l}\text { Rationalization number of dairy cows from } 7 \text { to } 5 \text {, } \\
\text { grass production still same }(147.355 \mathrm{~kg} / \text { day }) \text {, grass } \\
\text { necessity from } 210 \text { to } 150 \mathrm{~kg} / \mathrm{day} \text {, decreasing } \\
\text { intervention from } 0.492 \text { to } 0.004 \text { and increasing } \\
\text { biodiversity GMNP from } 0.451 \text { to } 0.707 \text {. }\end{array}$ & $\begin{array}{l}\text { synergizing function } \\
\text { of private lands } \\
\text { (homegarden, dry } \\
\text { field and land village } \\
\text { as a unit }\end{array}$ \\
\hline $\mathrm{AF} 2$ & SAR2 & $\begin{array}{l}\text { Pruning } 10 \% \text {, increasing grass productivity from } \\
108.947 \text { to } 121.212 \mathrm{~kg} / \text { day, grass necessity from } 125 \text { to } \\
120 \text {, intervention level decreasing from } 0.110 \text { to } 0.000 \\
\text { and GMNP biodiversity from } 0.595 \text { to } 0.709 \text {. }\end{array}$ & $\begin{array}{l}\text { management) and } \\
\text { intensification by } \\
\text { land tillage, renewal } \\
\text { of grass and }\end{array}$ \\
\hline AF3 & SAR3 & $\begin{array}{l}\text { Pruning } 30 \% \text {, rationalization number of dairy cows } \\
\text { from } 2.75 \text { to } 7 \text {. Grass productivity increase from } \\
216.279 \text { to } 301.943 \mathrm{~kg} / \text { day, grass necessity from } 83 \text { to } \\
210 \text {, decreasing intervention level of GMNP from } \\
0.002 \text { to } 0.000 \text { and increasing biodiversity from } 0.703 \\
\text { to } 0.709 \text {. }\end{array}$ & $\begin{array}{l}\text { fertilization with } \\
\text { changes in refocusing } \\
\text { function of: } \\
\text { 1.homegarden } \\
\text { focusing to vegetable } \\
\text { and MPTS. }\end{array}$ \\
\hline AF4 & SAR4 & $\begin{array}{l}\text { Number of dairy cows rationalization from } 8 \text { to } 6 \text {. } \\
\text { Grass production still same (188.598 } \mathrm{kg} / \text { day), grass } \\
\text { necessity from } 240 \text { to } 180 \mathrm{~kg} / \text { day, intervention level } \\
\text { decreasing from } 0.077 \text { to } 0.000 \text { and increasing } \\
\text { biodiversity GMNP from } 0.658 \text { to } 0.709 \text {. }\end{array}$ & $\begin{array}{l}\text { 2. dry field focusing } \\
\text { grass, fast growing } \\
\text { species with low } \\
\text { crown density mixer } \\
\text { with slow growing }\end{array}$ \\
\hline AF5 & SAR5 & $\begin{array}{l}\text { Pruning } 30 \% \text {. Increasing grass production from } 97.489 \\
\text { to } 126.285 \mathrm{~kg} / \text { day, grass necessity from } 118 \text { to } 120 \\
\mathrm{~kg} / \text { day, decreasing intervention level of GMNP from } \\
0.012 \text { to } 0.000 \text { and increasing biodiversity from } 0.690 \\
\text { to } 0.709 \text {. }\end{array}$ & $\begin{array}{l}\text { species. } \\
\text { 3. land village } \\
\text { focusing on grass and } \\
\text { fast growing species. }\end{array}$ \\
\hline
\end{tabular}

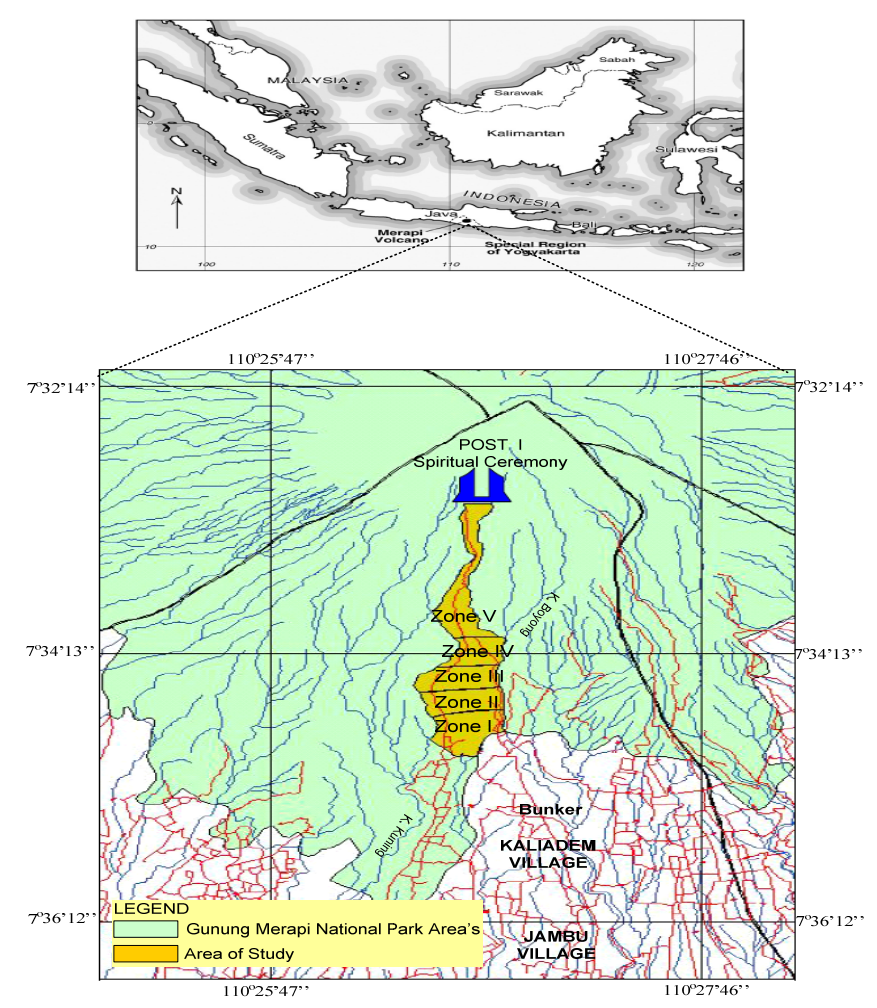

Figure 1. Location of the study 


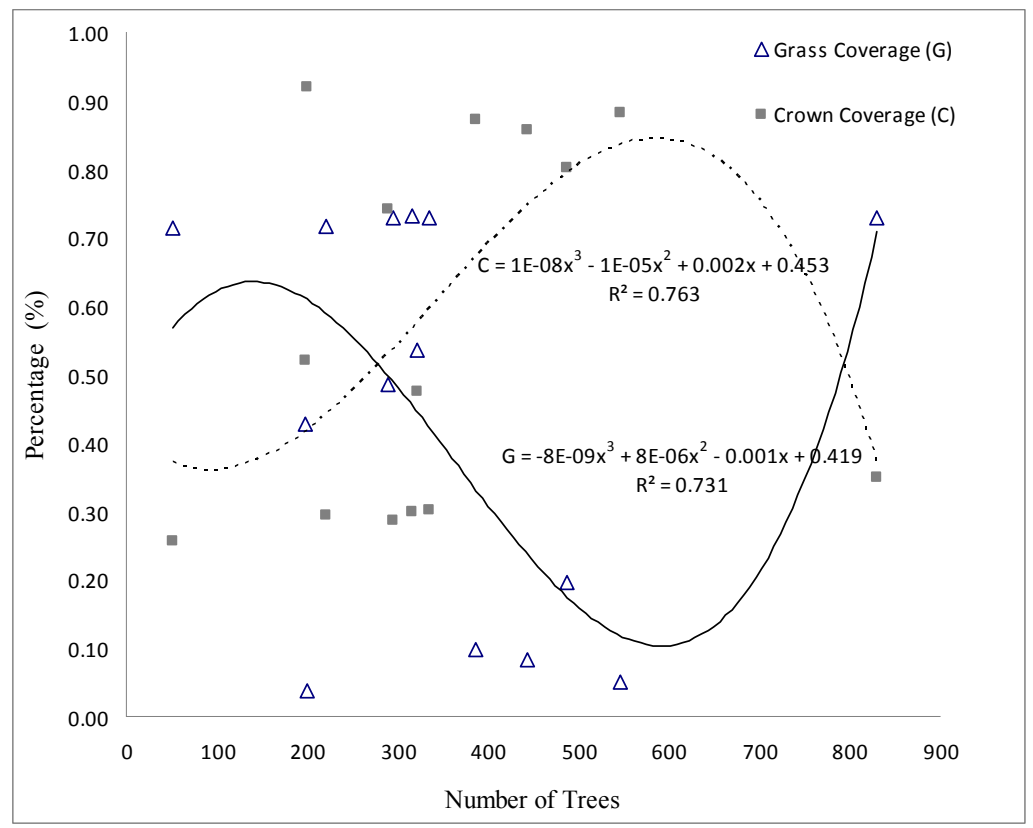

Figure 2. Trend showing the relationship between trees-grass coverage and tree-crown coverage

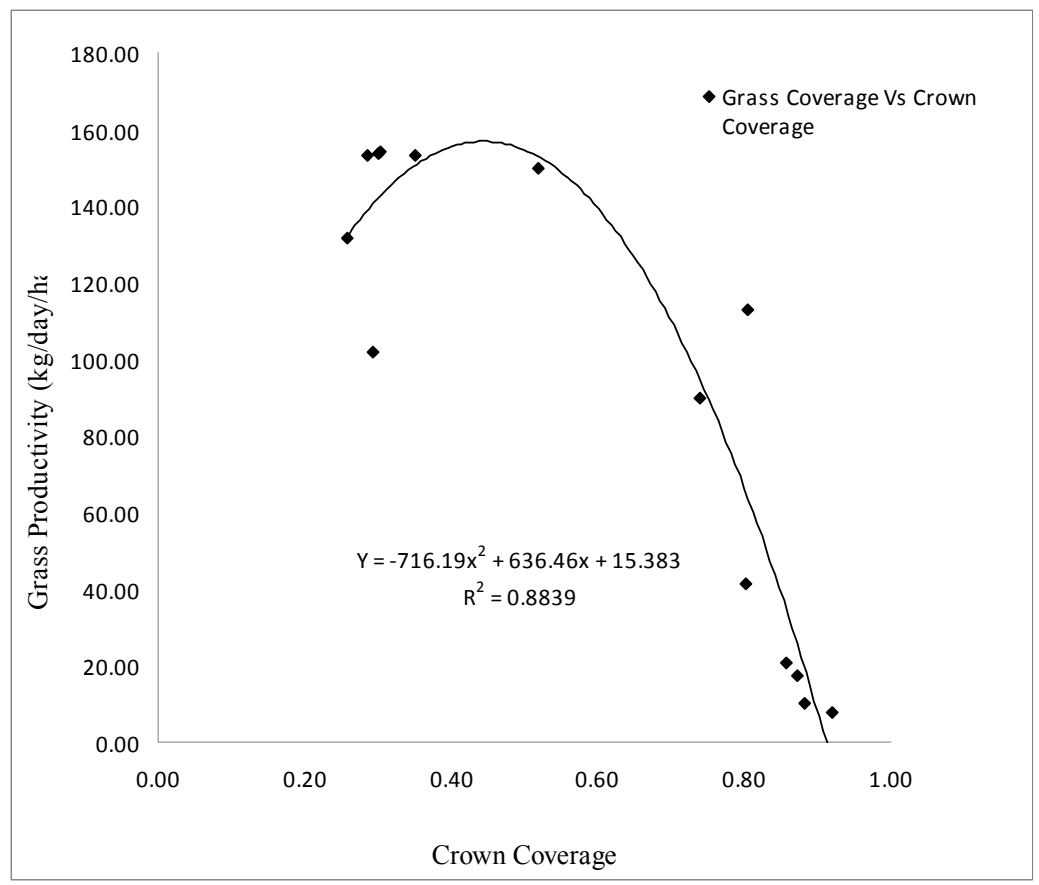

Figure 3. The relationship between grass productivity and crown coverage 


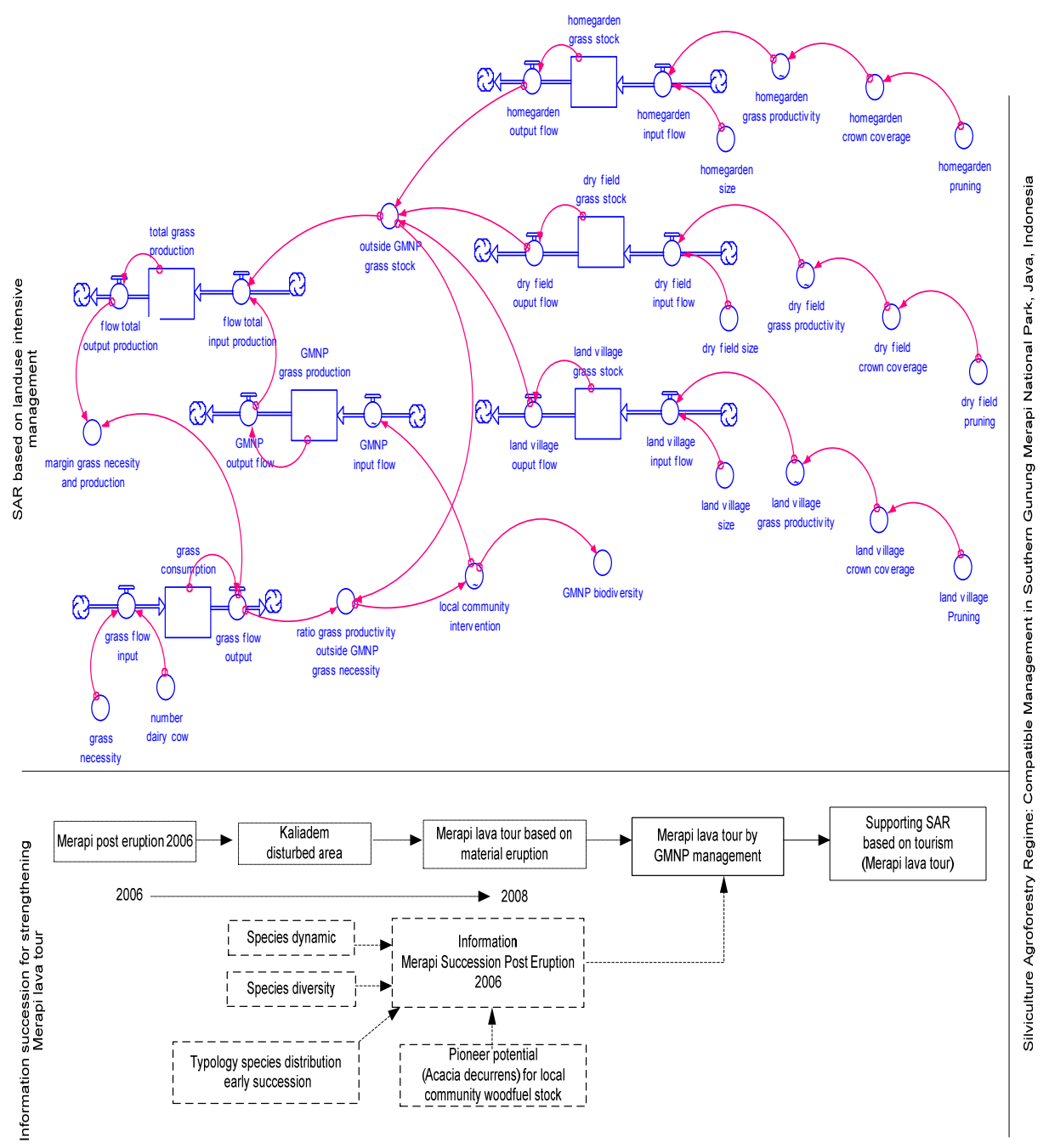

Figure 4. Schematic model of silviculture agroforestry regime

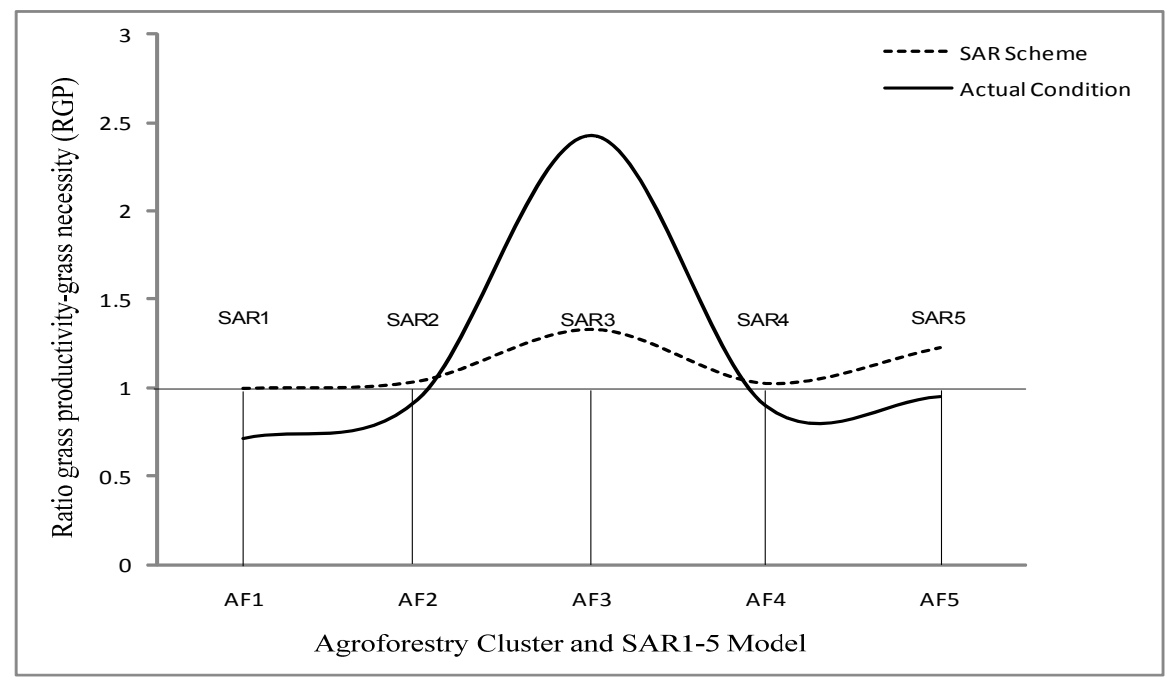

Figure 5. The trend ratio of grass productivity outside the GMNP and grass necessity after the implementation of SAR 1 to SAR5 